\title{
MENYIASATI RUANG, MENEBAR KEDAMAIAN
}

\author{
Dedi Slamet Riyadi \\ KUA Kec. Lebakwangi Kab. Kuningan, Jawa Barat \\ dediahimsa@gmail.com \\ Judul : Ketika Agama Bawa Damai, Bukan Perang \\ Belajar dari "Imam dan Pastor" \\ ISBN $\quad$ : 978-979-772-057-5 \\ Editor : Ihsan Ali-Fauzi \\ Tebal : iv+241 hal. \\ Cetakan : I, September 2017 \\ Penerbit : Pusat Studi Agama dan Demokrasi (PUSAD), \\ Yayasan Wakaf Paramadina, Jakarta
}

To me, its nonsense - and very dangerous nonsens at that - all this talk of I'm Tajik and you're Pashtun and he's Hazara and she's Uzbek. We're all afghans, and that's all that should matter. But when one group rules over the others for so long ... there's contempt. Rivalry. There is. There always have been.

(Khaled Hosseini, 2007: 117)

\section{DUA SISI AGAMA}

Ketika ulasan ini ditulis, ada beberapa fenomena penting yang terjadi di beberapa belahan dunia. Pada hari Jumat, 24 Nopember, sekitar 15 orang bersenjata api, granat tangan, dan bom rakitan menyerbu memasuki Masjid ar-Raudhah di Sinai Mesir lalu memberondongkan senapan mesin, menembaki para jamaah yang tengah melaksanakan ibadah shalat Jumat secara brutal. Mereka membunuh para jamaah di masjid itu secara keji hingga diaporkan bahwa dari lebih 300 orang yang terbunuh di masjid itu, 20 orang di antaranya anak-anak, dan ratusan orang yang terluka parah. Salah seorang penyintas yang menyaksikan serangan brutal itu menggambarkan bahwa para penyerang menyerbu memasuki masjid lalu secara keji dan brutal menembaki kaum muslim yang sedang berjamaah shalat Jumat. Mereka memberondongkan senapan mesin sambi terusmeneriakkan kata-kata keji, seperti "Jangan ada seorang pun yang selamat! Habisi mereka semua!" Ketika ada jamaah yang telah tertembak tetapi masih terlihat bernafas, para penyerang itu kembali menembakkan sepanannya kepada jamaah itu untuk memastikan kematiannya. Ada pula sebagian penyintas yang mendengar para penyerang itu meneriakkan kalimat suci, "Allahu Akbar".

Sebagian kalangan menduga bahwa para penyerang itu kemungkinan besar berasal dari kelompok garis keras bersenjata setempat yang berafiliasi denganISIS - walaupunhinggakinibelum ada pihak yang mengaku bertanggung jawab atas kekejian tersebut. Dugaan disandarkan atas keteranga Jaksa Agung Mesir, seperti ditulis CNN. Menurut lembaga tersebut, penyerang membawa panji-panji hitam ISIS, menumpang lima SUV, menenteng senjata berat, dan sebagian darinya memakai baju perang aau bermasker. Peristiwa ini seakanakan makin menegaskan pandangan sebagian kalangan yang meyakini agama sebagai sumber kekerasan. Ada sejumlah peristiwa serupa lain yang terjadi di beberapa belahan dunia Islam. 
Beberapa pekan sebelum pembantaian di Sinai, sebuah masjid di Pakistan dibom yang menewaskan setidaknya 70 orang dan melukai lebih dari 200 orang lainnya. Empat bulan sebelumnya, ISIS membantai 52 orang di sebuah makam seorang sufi. Dan pada April 2011 pelaku bom bunuh diri membunuh 41 orang sufi pada sebuah perayaan keagamaan. (https://beritagar.id/artikel-amp/laporankhas/pembantaian-di-sinai-dan-sufiyang-disalahpahami, diakses 3 Desember 2017).

Sebagaimana diungkapkan Irsyad Rafsadi, salah seorang kontributor dalam buku ini, berbagai peristiwa konflik sosial menebalkan pandangan sebagian orang bahwa agama merupakan biang kekerasan. Ia menyatakan, jika kita mencoba melakukan pencarian di mesin pencari menggunakan kata kunci "agama" dan "perdamaian" maka hasilnya akan jauh lebih sedikit daripada pencarian dengan kata kunci "agama" dan "kekerasan". Banyak konten di dunia maya yang membicarakan agama sebagai biang kekerasan dan hanya sedikit yang melihatnya sebagai bagian dari solusi terhadap kekerasan. Ia juga mengungkapkan bahwa tidak sulit bagi siapa pun untuk mencari ajaran agama yang mendukung kekerasan atau contohcontoh penganut agama yang berperang di bawah panji agamanya. (hal. 29)

Ungkapan senada disampaikan editor buku ini, Ali Ihsan Fauzi, yang menyatakan dalam pengantarnya bahwa hubungan antara agama dan kekerasan merupakan hubungan yang ditandai oleh ambiguitas, sifat mendua, yang sangat nyata. Kalangan agamawan tertentu boleh saja mengklaim bahwa orientasi kepada perdamaian sudah intrinsik ada dalam tradisi agama-agama. Namun, ujarnya, di sisi lain, juga dapat dibenarkan jika dikatakan bahwa agama secara intrinsik dapat memancing terjadinya konflik dan kekerasan. (hal. 8)
Lebih jauh ia menjelaskan bahwa fungsi agama sebagai pemberi atau penanda identitas seseorang atau kelompok dapat berkembang lebih jauh ke dalam apa yang mencirikan pola utama kekerasan keagamaan selama ini, yaitu pemberian legitimasi kepada penggunaan kekerasan (bersenjata) dalam jihad besar (atau crusade), "perjuangan suci" melawan kelompok lain, kelompok "mereka". (hal. 9) Pada tahap berikutnya, agama "membenarkan" aksi kekerasan, karena komunitas agama tertentu-kelompok "kita" - pada akhirnya memerlukan sebuah ruang dan wilayah di mana "kita" bisa unggul dan mendominasi. (hal. 10)

Meskipun kenyataan itu tidak terbantahkan, kita juga tidak bisa mengabaikan fakta lain yang menunjukkan kebalikannya, yakni bahwa ajaran-ajaran agama sering menjadi faktor pendorong dan sumber ilham bagi parap egiat perdamaian untuk mencari solusi damai atas konflik sosial yang terjadi di berbagai belahan dunia. Buku ini, secara khusus akan mengulas berbagai upaya yang dilakukan kau agamawan untuk menjadikan agama sebagai sumber energi untuk membangun perdamaian. Karena itulah buku ini dijuduli "Ketika Agama Bawa Damai, Bukan Perang, Belajar dari 'Imam dan Pastor'". Judul buku itu tidak menafikan adanya sebagian kaum beragama yang menjadikan agama sebagai landasan gerak dan laku kekerasan terhadap komunitas yang berbeda keyakinan dengan mereka. Namun, di sisi lain, judul itu menegaskan pentingnya upaya untuk menjadikan agama sebagai sumber dan pendorong terciptanya perdamaian.

Ketika menjadi pembicara kunci dalam lokakarya "Pitch for Peace" yang diselenggarakan oleh The Wahid Institute, Menteri Agama, Lukman $\mathrm{H}$. Saifuddin mengatakan bahwa esensi dan substansi agama harus menjadi ruh bagi gagasan utama menebarkan 
perdamaian dunia. Keberagaman dan keberagamaan seharusnya menjadi sumber dan dasar penting untuk mewujudkan harmoni sosial (Kompas, 2/9/2015). Ungkapan Menteri Agama itu menegaskan pentingnya nilai agama bagi upaya untuk mewujudkan kedamaian di Indonesia, bahkan di seluruh dunia. Nilai itu pulalah yang digambarkan dalam buku ini. Secara khusus buku ini diterbitkan untuk menyambut kedatangan Imam Muhammad Ashafa dan Pastor James, dua agamawan pekerja binadamai dari Nigeria. Pada awalnay mereka merupakan musuh sengit, lalu mengalami "transformasi spiritual" menjadi pengusung perdamaian di negara mereka.

\section{BINADAMAI MERUPAKAN KEWAJIBAN SEMUA KALANGAN}

Istilah binadamai banyak dipergunakan dalam buku ini karena istilah itu dianggap lebih positif dan mengandung makna yang lebih luas, mencakup di dalamnya resolusi konflik, serta upaya-upaya pencegahan, pengelolaan, transformasi, dan migitasi konflik. Selain itu, sasaran binadamai juga dianggap lebih luas dari sekadar menyelesaikan konflik, tetapi mencakup banyak persoalan yang saling terkait, dari mencegah kekerasan hingga mewujudkan keadilan dan kesejahteraan. Karenanya, istilah binadamai sering disebut juga strategic peacebuilding (hal. 31). Penggunaan istilah ini mengindikasikan makna bahwa jika kita berkepentingan untuk menjaga dan membangun perdamaian, kita tidak bisa mengabaikan agama.

Sebagaimana tersurat dalam judul, buku ini secara khusus didedikasikan untuk menyambut kedatangan Sang Imam dan Pastor dari Nigeria. Ada satu tulisan khusus dengan judul "Agama, Kekerasan, dan Binadamai di Nigeria:
Pelajaran dari 'Imam dan Pastor'", yang mengulas kiprah dua agamawan penting asal Nigeria yang tanpa kenal lelah berupaya membangun dan mengampanyekan perdamaian di negara mereka. Tulisan itu memaparkan kisah hidup mereka, khususnya latar belakang agama, budaya, dan pendidikan mereka serta transformasi mereka dari pemimpin agama yang membenarkan aksi-aksi kekerasan atas nama agama menjadi pengecam kekerasan yang istikamah.

Kisah perjuangan mereka memberi gambaran bahwa upaya perdamaian akan lebih diwujudkan jika kedua pemimpin yang berseteru mengalami transformasi personal sehingga keduanya bisa kompak bekerja sama memperjuangkan perdamaian. Namun, fenomena seperti Imam dan Pastor ini sangat jarang terjadi. Sebab, langkah untuk mendekat dan secara tulus merangkul serta menerima dan memaafkan pihak yang sekian lama dianggap musuh membutuhkan tekad dan kekuatan mental yang kukuh. Para pemuka agama kerap menjadi target utama berbagai pihak yang menghendaki kekuasan karena mereka memiliki pengaruh yang besar terhadap para pengikutnya. Fenomena seperti ini terjadi pula di belahan dunia lain, seperti di Liberia yang mengalami konflik sosialagama berkepanjangan. Laporan akhir komisi Truth and Reconciliation Liberia (2012: 18), mengungkapkan:

Military leaders and combatants sought the blessing and support of religious and traditional leaders for protection during battle. Such protection was offered by religious and traditional leaders in the form of prayers, blessings, charms and secret practices that were designed to provide protection from harm, such as "bullet protection." Some religious bodies solicited financial support for various factions. [Subcommittee County Outreach; Harper, 2007] 
Pasukan dan kaum militan yang terlibat dalam konflik bersenjata selalu menjadikan para pemimpin agama sebagai rujukan, tempat bertanya, bahkan tempat meminta perlindungan sebelum menghadapi musuh masingmasing. Maka, upaya untuk mewujudkan perdamaiannya pun harus melibatkan para pemimpin agama. Laporan yang sama mengungkapkan bahwa para pemimpin agama dan lembaga-lembaga tradisional aktif melakukan upayaupaya damai yang akhirnya berujung pada penandatangan perjanjian damai di Akra, Ghana pada 2003. Upaya itu dimaksudkan untuk meredakan ketegangan antarpemeluk agama yang berbeda dan konflik antaretnis melalui dialog kerjasama yang melibatkan berbagai kelompok yang bertikai. Upaya ini memberikan kontribusi pada terbentuknya Economic Community of West African States (ECOWAS).

Pemimpin agama memiliki peran yang sangat penting baik dalam eskalasi kekerasan maupun dalam upaya-upaya binadamai. Peran mereka tidak dapat diabaikan, karena dalam sistem religiopolitik, kalangan awam (para pengikut) akan mengikuti secara buta dan menganggap pemimpin mereka sebagai wakil Allah yang menegakkan agama dan menyelamatkan mereka dari tirani dunia (Thohir, 2002: 152). Sebagaimana dikatakan oleh Smith, sistem religio-politi selalu ditandai dengan tiga komponen penting, yaitu ideologi keagamaan yang bersifat integralis, mekanisme pengendalian keagamaandi masyarakat, dan kekuasaan politik yang dominan. Ketiga komponen agama ini harus dilibatkan jika kita hendak melakukan upaya-upaya binadamai (Smith, 1985: 8586).

Paparan mengenai Imam dan Pastor serta fenomena yang terjadi di Liberia menunjukkan pentingnya pemerintah dalam upaya binadamai. Kampanye perdamaian yang diusung Imam Ashafa dan Pastor James tidak akan berhasil jika tidak didukung oleh kebijakan-kebijakan pemerintah. Karena itulah kedua pemuka agama itu terus-terusan menggalang berbagai dukungan dari pemerintah, baik eksekutif amupun legislatif untuk bersama-sama menjalankan programprogram perdamaian. (hal. 59-65). Gambaran itu pulalah yang kita dapatkan dari bagian lain buku ini yang bertutur tentang fenomena hubungan Muslim-Kristen di Kupang. Stella Aleida Hutagalung (hal. 157-188) menunjukkan bahwa pemimpin politik atau penguasa daerah memiliki peran penting dalam upaya menciptaan dan menjaga perdamaian. Ia menuturkan, terkait insiden November 1998, kerusuhan yang dipicu oleh berita tentang kerusuhan anti-Kristen di Ketapang, Jakarta, pemerintah mampu bersikap tegas dan mengambil langkah-langkah penting untuk segera mengendalikan situasi. Pemerintah mampu berkoordinasi secara efektif dengan pemuka agama dan tokoh masyarakat. Tingginya kepercayaan umat Muslim terhadap Gubernur NTT yang beragama Kristen (Piet Tallo, 19982008) merupakan faktor penting dalam mencegah eskalasi konflik. Setelah terjadinya kerusuhan itu, Gubernur dan jajarannya langsung mengunjungi masjidmasjid yang rusak dan secara terbuka mengutuk kekerasan serta meminta maaf kepada para korban. Tidak hanya itu, ia juga memberikan ganti rugi atas kerusakan bangunan dan memberikan bantuan untuk merenovasi masjid dan rumah yang rusak. (hal. 174)

Hal lainnya yang juga penting dikemukakan dari bagian ini adalah bahwa transformasi personal yang dialami oleh Imam Ashshafa dan Pastor James tidak terjadi tiba-tiba. Keduanya, diawali oleh Imam Ashshafa mengalami pergulatan batin yang cukup panjang hingga akhirnya masing-masing bisa menerima "musuhnya' dan kemudian 
bekerja sama melakukan aksi-aksi binadamai. Satu hal yang turut andil mengubah pandangan dan keyakinan mereka untuk beralih dari kekerasan kepada binadamai adalah khutbah yang didengar keduanya di lingkungan dan tradisi agamanya masing-masing. Imam Ashshafa tersentak oleh kampanye perdamaian yang dituturkan seorang khatib di masjid, begitu pula Pastor James yang mulai tergugas setelah mendengar khutbah di gereja. (hal. 51 dan 56) Indonesia bisa belajar dari fenomena itu. Akan sangat menawan jika masjid, gereja, pura, wihara, dan tempat-tempa ibadah lainnya mengampanyekan dan menyebarkan ajaran-ajaran kelembutan, perdamaian, dan kasih sayang, alihalih menebarkan kebencian, dendam, dan kecaman kepada pihak-pihak yang berbeda keyakinan.

Bagianlainbukuinimenggambarkan upaya berani yang dilakukan para agamawan perempuan dalam rekonsiliasi dan binadamai di wilayah konflik Maluku, Indonesia bagian Timur (hal. 81-116). Istilah "agamawan perempuan" merujuk kepada (1) sekelompok perempuan yang visi dan misi mereka diilhami oleh pengetahuan, wacana, dan tradisi agama; dan (2) perempuan yang aktif dalam lembaga, jaringan, dan kelompok-kelompok keagamaan. Bagian ini secara khusus membahas berbagai upaya binadamai yang dilakukan para agamawan perempuan dari kalangan Muslim, Protestan, dan Katolik. (hal. 8182)

Tulisan ini merupakan laporan hasil penelitian yang dilakukan penulis di wilayah konflik Maluku. Penelitiannya itu didorong oleh keprihatinan melihat minimnya ulasan, bahkan nyaris tidak ada uasan, mengenai peran penting kaum perempuan dalam upaya rekonsiliasi dan binadamai di Maluku, baik oleh kalangan akademiksi maupun analis kebijakan. Padahal, sebagaimana kemudian dilaporkan penulis, perempuan memiliki peran besar alam upaya rekonsiliasi pihak-pihak yang bertikai dan mencegah terjadinya kekerasan baru, baik di Maluku maupun daerah konflik lainnya di Indonesia. Pembahasan mengenai peran perempuan dalam upaya-upaya binadamai penting dikemukakan karena dalam berbagai konflik sosial, khususnya yang dipicu oleh nilai-nilai agama, suku, dan ras, kaum perempuan selalu menjadi kelompok yang paling menderita. Ketika dua pasukan berperang dan saling mengalahkan, kaum perempuan selalu menjadi korban yang paling menderita. Berbagai peristiwa menunjukkan fakta itu, seperti yang dialami oleh Malala Yousafzai-peraih Nobel Perdamaian pada 2014 bersama Kaliash Satyarthiyang ditembak di kepala dan leher dalam upaya pembunuhan oleh kelompok bersenjata Taliban. Saat itu ia baru berusia 15 tahun. Ia ditembak karena bersikap kritis terhadap kelompok militan. Kaum perempuan di Afghanistan, Rohingya, dan di berbagai wilayah konflik lainnya, selalu menjadi kelompok masyarakat yang paling menderita. Fenomena seperti itu misalnya terjadi di Liberia, sebagaimana dikemukakan oleh Julie Xuan Oullet (2013: 13):

For over a decade, Liberian women had suffered unimaginable atrocities; "those who were not brutally murdered experienced and/or witnessed unimaginable acts of sexual brutality, mutilation, cannibalism, and torture" (Goodfriend \& Pillay, 2009, p. 11). From 1989 to 2003 , over $80 \%$ of Liberian women were sexually assaulted (Goodfriend \& Pillay, 2009); many were raped with objects including blades and knives. Most lost their homes, their access to drinking water, and their children who were systematically recruited as soldiers (Berkley Center for Religion, Peace \& World Affairs, 2011, p. 7).

\begin{tabular}{l|l} 
Jurnal Multikultural \& Multireligius Vol. 16 & No. 2
\end{tabular} 
Kekejian seperti itu pulalah yang terjadi dalam berbagai kerusushan dan pertikaian sosial. Kaum perempuan menjadi pihak yang paling berat menanggung penderitaan. Ketika kaum laki-laki-para suami dan anak mudapergi berperang, para perempuan tetap tinggal di tempat mereka sambil terus menjaga dan mencari makanan serta tempat berlindung untuk untuk anakanak mereka yang masih kecil. Secara emosional merekalah yang paling berat menanggung kesedihan, karena setiap saat diliputi rasa khawatir jika sewaktuwaktu milisi musuh menyerbu tempat tinggal mereka; hati mereka juga selalu diliputi kesedihan membayangkan nasib para suami dan anak laki-laki mereka yang pergi berperang. Kesedihan dan penderitaan seperti itu pulalah yang digambarkan pada bagian ini (hal. 8892). Berdasarkan kenyataan itulah, sejumlah agamawan perempuan, baik dari Katolik, Muslim, maupun Protestan bersama-sama bergerak mengupayakan rekonsiliasi dan binadamai. Pada tahun 2002, didorong oleh keinginan dan komitmen untuk mengakhiri pertempuran, Tualeka mendirikan Lingkar Pemberdayaan Perempuan dan Anak (Lappan) yang bertujuan untuk melakukanupaya pemulihan pascaperang di wilayah tersebut. (hal. 92). Tokohtokoh perempuan lainnya mendirkan aliasnsi antaragama bernama Gerakan Perempuan Peduli pada bulan Agustus 1999. Tidak lama berselang berdiri pula Gerakan Baku Bae yang digagas oleh para tokoh agama dan tokoh masyarakat dari kalangan Muslim dan Kristen. Diawali oleh kelompok perempuan Katolik dan Protestan, anggota elit GPP merekrut pemimpin danaktivis Muslim untuk bergabung dengan kelompok tersebut. (hal. 93)

Maka, mulailah para perempuan pemberani itu melakukan berbagai aksi binadamai. Mereka mengampanyekan kepada para suami dan anak-anak yang ikut berperang untuk menghentikan peperangan. Mereka juga terus mendorong pemerintah untuk terus melakukan upaya-upaya binadamai meskipun para militan dari kedua pihak menentang perjuangan mereka. Salah satu gerakan yang cukup fenomenal adalah mengampanyekan pemakaian ikat kepala hijau dengan tulisan "hentikan kekerasan". Kampanyeitu terus menyebar ke seluruh penjuru Maluku. Upayaupaya rekonsiliasi itu membuahkan hasil dengan diterimanya petisi kaum perempuan yang disebut "Hati Nurani Perempuan". Petisi untuk menghentikan peperangan itu menyeru pemerintah untuk menghentikan kekerasan serta meminta orang Kristen dan Muslim untuk berdamai, membangun kembali persaudaraan yang hancur karena konflik. (hal. 96).

Beberapa tulisan yang dihimpun dalam buku ini menggambarkan bahwa upaya rekonsiliasi dan binadamai tidak aan berhasil jika hanya dilakukan secara sepihak dan tidak dijaga secara istikamah. Berbagai pihak yang bertika harus dengan tulus berusaha saling menerima, saling memaafkan, dan bekerja sama melakukan upaya-upaya binadamai. Selain itu, hal lain yang penting dilakukan adalah menjaga kedamaian yang telah tercipta agar konflik sosial tidak terjadi lagi. Peristiwa berulangnya konflik sosial, seperti yang terjadi di Ambon dan di Kupang menunjukkan bahwa jika pemerintah dan masyarakat tidak bersikap waspada menghadapi embus angin kebencian dan permusuhan, isuisu kecil bisa dengan cepat mengobarkan peperangan antarpemeluk agaa atau antaretnis. Di sinilah pentingnya upaya untuk mewaspadai berbagai informasi yang beredar di tengah masyarakat. 
PERAN MEDIA DALAM PENYEBARAN KEKERASANDANKAMPANYEBINADAMAI

Sejak baris-baris pertama, buku ini mengemukakan kritik penting terhadap kecenderungan industri informasi dan komunikasi massa yang banyak mengungkapkan sisi buruk ekspresi sosial-politik dari agama-agama. Editor buku ini seakan-akan hendak mengantarkan pembaca kepada paparan realitas yang lebih jauh tentang bagaimana media massa dan industri informasi turut andil dalam menyebarkan citra buruk agama-agama:

Dalam model pemberitaan seperti ini orang-orang dengan motivasi keagamaan itu disebut dengan kata-kata seram: zealots, extremists, militants-belakangan, terrorist. Kadang-kadang liputan itu dilengkapi dengan ilustrasi foto yang mengerikan, membangunkan bulu kuduk. Model pemberitaan yang sebaliknya, berisi kisah yang enak didengar, misalnya tentang upaya-upaya perdamaian oleh kalangan agamawan, amat jarang ditemukan . (hal. 3)

Namun sayang, sebagaimana bisa kita lihat, tidak ada satu pun tulisan dalam buku ini yang membahas peran media massa dan industri informasi dalam eskalasi maupun deeskalasi konflik sosial. Padahal, sebagaimana ditekankan pada bagian awal pengantarnya, editor mengemukakan bahwa media massa dan teknologi informasi berperan penting terhadap penyebaran budaya kekerasan dalam kehidupan beragama. Menurutnya, pemberitaan mengenai kekerasan berjubah agama seharusnya mengungkapkan pula akar-akar kultural dan struktural terjadinya kekerasan itu. (hal. 4) Lebih jauh ia menyatakan bahwa model peliputan yang saat ini berkembang dianggap tidak berorientasi kepada penyelesaian konflik dan pengupayaan perdamaian. Atau, setidak-tidaknya lebih merugikan daripada menguntungkan.

Absennya pembahasan tentang peran media massa terhadap perdamaian atau kekerasan yang dipicu oleh masalahmasalah agama penting dikemukakan karena perkembangan mutakhir menunjukkan betapa media massa dan industri informasi berkontribusi besar terhadap penyebaran hate culture dan kekerasan atas nama agama. Masih segar dalam ingatan bagaimana kepolisian membongkar sejumlah jaringan informasi yang menebarkan kebencian dan berbagai informasi yang menyesatkan (hoax). Ditengarai bahwa para produsen informasi hoax dan ujaranujaran kebencian itu berperan besar dalam pembentukan opini massa yang mengarah kepada disintegrasi sosial.

Pembahasan mengenai peran media massa dan industri informasi dianggap penting dikemukakan karena sejumlah teori membuktikan bahwa media massa memiliki peran penting terhadap pembentukan opini publik. Gerbner dan Gross, misalnya mengungkapkan Teori Kultivasi yang menguraikan bahwa orang yang sering menonton televisi lebih mudah menerima pesan komunikasi media tersebut dan menganggap apa yang mereka tonton sebagai sesuatu yang nyata dan valid. Kelompok pengguna media seperti ini disebut juga heavy viewers. Mereka sering terekspos kepada kekerasan dan karena itu terkena Sindrom Dunia Kejam yaitu suatu anggapan bahwa dunia jauh lebih buruk dan berbahaya dari situasi sebenarnya (Gerbner, 1976: 172-199). Teori lainya adalah Spiral of Silence Theory yang dikemukakan oleh Elisabeth Noelle-Neumann (1991) yang menjelaskan kecenderungan orang untuk bungkam saat mereka merasa pandangan mereka bertentangan dengan pemikiran mayoritas mengenai suatu topik tertentu. Faktor penyebab kebungkaman ini adalah ketakutan diisolasi oleh kelompok serta ketakutan ditekan atau diisolasi ekstrem dalam 
pengertian konsekuensi negatif lainnya. Media massa berperan penting dalam proses tersebut, terutama dalam menentukan atau membentuk persepsi yang mewrijud menjadi pendapat mayoritas.

Adapun mengenai peran media massa terhadap pembentukan opini publik, Maxwell McCombs dan Donald Show menguraikannya dalam "The Agenda Setting Function of the Mass Media" yang dipublikasikan pada 1927 dalam Public Opinion Quarterly. Dikenal sebagai Teori Agenda Setting, teori ini menyatakan bahwa media menentukan agenda publik, dalam pengertian media mungkin tidak secara eksplisit memberitahu apa yang harus khalayak pikirkan, tetapi media memberitahu untuk berpikir tentang suatu hal tertentu (McCombs, 2003: 17). Juga ada Teori Framing yang dikemukakan oleh Erving Goffman. Goffman menyatakan bagaimana sesuatu disampaikan kepada publik. Frame atau "bingkai" memengaruhi memengaruhi pilihan yang dibuat orang mengenai bagaimana mereka memproses informasi tersebut. Bingkai adalah abstraksi yang mengorganisir atau menyusun makna pesan (Goffman, 1974:53).

Jadi, sebagaimana dikatakan Tatang Mutaqin (2006: 9-11), selain memiliki peran positif seperti menyebarkan dan memperkuat kesepahaman antarwarga, media massa juga memiliki peran negatif, yang dapat merusak tatanan dan harmonis sosial, di antaranya:

Pertama, media memiliki kekuatan 'penghakiman' sehingga informasi yang stereotype, bias, dan cenderung imaging yang tidak sepenuhnya menggambarkan realitas bisa tampak seperti kebenaran yang terbantahkan. Kedua, media memiliki kekuatan untuk menganggap biasa suatu tindakan kekerasan. Program-program yang menampilkan kekerasan yang berbasiskan etnis, bahasa dan budaya dapat mendorong dan memperkuat kebencian etnis dan perilaku rasis. Ketiga, media memiliki kekuatan untuk memprovokasi berkembangnya perasaan kebencian melalui penyebutan pelaku atau korban berdasarkan etnis atau kelompok budaya tertentu. Keempat, pemberitaan yang mereduksi fakta sehingga menghasilkan kenyataan semu (false reality), yang menguntungkan kepentingan tertentu dan sekaligus merugikan kepentingan pihak lain (Mas'udi, 2013: 212).

Dengan demikian, di tengah derasnya arus informasi dan pesatnya kemajuan teknologi informasi, upayaupaya binadamai harus melibatkan penggunaan media massa dan industri informasi. Media massa dan juga media sosial yang nyaris tidak terpisahkan dari keseharian masyarakat harus dijadikan sebagai media untuk mempromosikan perdamaian, keamanan, pembangunan berkelanjutan, melalui pendidikan agama yang baik. Para pemimpin agama dan pemerintah harus menjadikan media massa sebagai sarana untuk menyebarkan nilai-nilai agama yang baik, menunjukkan nilai-nilai etis, toleransi, dan sikap saling memaafkan dalam berbagai situasi. Media massa juga bisa dijadikan sebagai sarana untuk mempromosikan dialog antara berbagai kelompok agama sehingga akan tercipta forum bersama untuk bertukar gagasan dan kesepahaman (Kamal, 2012: 1-5). Pada akhirnya, sebagaimana dikatakan Jalaluddin Rumi dalam Matsnawi-nya (2001: 283):

"All man-and woman-are the same. Purity and impurity, sloth and diligence in worship, these mean anything to me. I am apart from all that ways of worshipping are not to be ranked as better or worse than one another. Hindus do Hindu things, The Davidian Muslims in India do what they do. 
It is all praise, and it is all right. Its not I that is glorified in acts of worship. It is the worshippers! I do not hear the words they say. I look inside at the humility that brokenopen lowliness is the Reality, not the language! Forget phraseology. I want burning, burning. Be friends. Burn up your thingking and your forms of expressions!"

Buku ini, sebagaimana ditegaskan melalui judulnya, menggambarkan dengan lugas upaya keras tanpa kenal lelah dan berani yang dilakukan para "agamawan humanis"-istilah yang dipergunakan oleh penyunting buku ini untuk menyebut para pejuang binadamai-untuk mewujudkan dan menjaga perdamaian sesuai dengan kapasitas masing-masing. Rekam jejak perjuangan Sang Imam dan Pastor bisa menjadi pelajaran penting bagi bangsabangsa dan komunitas lainnya meskipun ada perbedaan dari sisi sosial, budaya, politik, maupun ekonomi dengan Nigeria yang menjadi medan perjuangan Sang Imam dan Pastor. Gambaran tentang berbagai upaya yang mereka lakukan bisa ditelaah dengan sangat baik karena mereka juga membuat rekaman audiovisual yang telah beredar luas dan diapresiasi banyak kalangan. Semoga Indonesia bisa belajar dari keduanya agar kedamaian tetap terjaga di negeri ini.

\section{DAFTAR PUSTAKA}

Gerbner, G \& Gross, "Living with Television: The Violence Profile”, Journal of Communication, vol. 26, no. 2, 1976.

Goffman, Erving, Frame Analysis: An Essay on the Organization of Experience, New York: Harper \& Row, 1974.

Hosseini, Khaled, A Thousand Splendid Suns, Bloomsbury Publisihing, London, 2007.

Mas'udi, Peranan Media dalam Membentuk Sosio-Kultur dan Agama Masyarakat: Menggagas Prinsip-Prinsip Etis dalam Jurnalistik, al-Tabsyir, Jurnal Komunikasi Penyiaran Islam, STAIN Kudus, volume 1, No 2, 2013.

McCombs, M, The Agenda-Setting Role of the Mass Media in the Shaping of Public Opinion, Texas: The University of Texas, 2003.

Olawale, Sulaiman Kamal-Deen dan Mrs Ojo Margaret Yemis, The Roles of Religious Education to Peace, Security and Sustainable Development in Nigeria, IOSR Journal of Humanities And Social Science (JHSS), ISSN: 2279-0837, ISBN: 2279-0845. Volume 3, 6 (Nov.-Dec. 2012).

Ouellet, Julie Xuan, Women and Religion in Liberia's Peace and Reconciliation, dalam Critical Intersections in Education: An OISE/UT Students' Journal, 1(1), 12-20, Winter 2013, ISSN: 2291-0697.

Rumi, Jalaluddin, Masnavi I Ma'navi, Teachings of Rumi, The Spiritual Couplets, Translated and abridged by E.H. Whinfield, M.A., Omphaloskepsis, Ames, Iowa, 2001.

Smith, Donald Eugene, Agama dan Modernisasi Politik, Jakarta: Rajawali Press, 1985.

The Truth and Reconciliation Commission of Liberia, The Role of Religious and Traditional 
Institutions during Conflict and in Peacebuilding, Final Report, Vol. 3: Appendices, Title IV: "The Conflict, Religion and Tradition", dalam Journal of Religion, Conflict, and Peace, Volume 5. Issue 1 and 2, Fall 2011-Spring 2012.

Thohir, Ajid, Gerakan Politik Kaum Tarekat, Telaah Historis Gerakan Politik Antikolonialisme Tarekat Qadiriyah-Naqsabandiyah di Pulau Jawa, editor: Dedi Ahimsa Riyadi, Bandung: Pustaka Hidayah, 2002.

\section{Media Massa}

Beritagar.id, Minggu, 3 Desember 2017, Pembantaian di Sinai dan Sufi Yang Disalahpahami.

H.U. Kompas, 2 September 2015. 